\title{
Tumor Necrosis Factor Alpha-308G/A Polymorphism and the Risk of Multiple Myeloma: A Meta-Analysis of Pooled Data from Twelve Case-Control Studies
}

\author{
Tümör Nekroz Faktör Alfa-308G/A Polimorfizmi ve Multipl Myelom Riski: On Iki Olgu Kontrol \\ Çalışması Havuz Datasının Meta Analizi
}

\author{
(D) Yingchao Li1, (D) Yong Lin2,3 \\ ${ }^{1}$ Xiamen University Zhongshan Hospital, Department of Orthopedics, Xiamen, China \\ 2Xiamen University Zhongshan Hospital Clinical Laboratory, Xiamen, China \\ ${ }^{3}$ Medical College of Xiamen University, Institute of Infectious Disease, Xiamen, China
}

\section{Abstract}

Objective: Tumor necrosis factor alpha (TNF- $\alpha$ ) is an important cytokine involved in inflammation, immune response, and other biological processes. The association between polymorphism -308G/A in its promoter and the risk of multiple myeloma (MM) is not clear. Thus, we conducted a meta-analysis to clarify this question.

Materials and Methods: Twelve eligible studies, which included 2204 MM cases and 3478 controls, were enrolled in our meta-analysis by searching the PubMed, China National Knowledge Infrastructure, Scopus, Web of Science, and Google Scholar databases up to December 2018. The effect of polymorphism -308G/A on MM risk was evaluated by calculating the pooled odds ratio (OR) and the 95\% confidence interval $(\mathrm{Cl})$. Furthermore, the 0 -test and 12 statistical analyses were used to estimate the degree of heterogeneity. Sensitivity analysis was conducted to test the robustness of the meta-analysis results. Publication bias was assessed by Egger's test and visual inspection of a funnel plot.

Results: In the dominant model, $-308 \mathrm{G} / \mathrm{A}$ polymorphism was associated with reduced $\mathrm{MM}$ risk $(\mathrm{OR}=0.80,95 \% \mathrm{Cl}$ : 0.65-0.97), and it also demonstrated a significant protective effect with a pooled OR of 0.82 (95\% Cl: 0.68-0.99) in the Caucasian subgroup. Because of the limited number of individual studies with AA genotype carriers, only eight studies were included in the recessive model, and no significant difference was observed. Moreover, the meta-analysis of the allele frequency demonstrated that the $\mathrm{A}$ allele has a protective effect against MM risk with a pooled OR of 0.83 (95\% Cl: 0.69-0.99). Sensitivity analysis suggested that the synthesized effect size was not influenced by any individual study. Moreover, the Egger's test statistical analysis suggested that publication bias was not obvious in the present analysis.

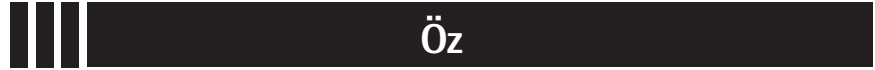

Amaç: Tümör nekroz faktör alfa (TNF- $\alpha$ ) enflamasyon, immün cevap ve diğer biyolojik süreçlerde rol alan önemli bir sitokindir. TNF- $\alpha$ -308G/A promotor bölge polimorfizmi ile multipl myelom (MM) riski arasındaki ilişki net değildir. Bu soruya cevap aramak amacıyla bir meta-analiz çalışması gerçekleştirdik.

Gereç ve Yöntemler: Meta analize 2018 Aralık ayına kadar PubMed, China National Knowledge Infrastructure, Scopus, "Web of Science", ve "Google Scholar"da yayınlanmış olan 2204 MM hastası ve 3478 kontrol içeren 12 çalışma dahil edildi. $-308 \mathrm{G} / \mathrm{A}$ polimorfizminin MM üzerine olan etkisi birleştirilmiş odds oranı (OR) ve \%95 güven aralığı (CI) ile değerlendirildi. Heterojenite derecesinin hesaplanması için 0-test ve 12 istatistiksel analizleri kullanıldı. Meta analiz sonuçlarının kuvvet testi için hassasiyet analizi kullanıldı. Yayın yanlılık değerlendirilmesi Egger testi ve huni grafiğinin görsel incelemesi ile yapıldı.

Bulgular: Baskın modelde, $-308 \mathrm{G} / \mathrm{A}$ polimorfizmi azalmış MM riski ile ilişkili bulundu $(\mathrm{OR}=0,80, \% 95 \mathrm{Cl}: 0,65-0,97)$, ve bu polimorfizm varlığının anlamlı koruyucu etkisi beyaz ırkta 0,82 (\%95 Cl: 0,68$0,99)$ birleştirilmiş OR ile de gösterildi. AA genotip taşıyıcılarının bireysel çalışmalarda daha az sayıda bulunması nedeniyle çekinik modele sadece 8 çalışma dahil edildi ve anlamlı bir farkılık gözlenmedi. Dahası, allel frekansının meta analizinde A allelinin MM için koruyucu etkisi 0,83 (\%95 Cl: 0,69-0,99) birleştirilmiş OR ile gösterildi. Hassasiyet analizi sentezlenen etki büyüklüğünde hiçbir çalışmanın tek başına belirleyici etkisinin olmadığını gösterdi. Ayrıca, Egger test istatistiksel analizi ile bu çalışmada yayın yanlıı̆̆ının olmadığını ortaya kondu.

๑Copyright 2019 by Turkish Society of Hematology

Turkish Journal of Hematology, Published by Galenos Publishing House

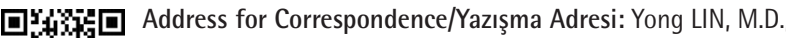

Xiamen University Zhongshan Hospital Clinical Laboratory, Xiamen, China

Phone : +86 5922993322

E-mail : mikhail929@163.com ORCID-ID: orcid.org/0000-0001-5120-8221

Received/Geliş tarihi: July 09, 2018 Accepted/Kabul tarihi: January 02, 2019 


\section{Abstract}

Conclusion: Overall, the $-308 \mathrm{G} / \mathrm{A}$ polymorphism was associated with reduced $\mathrm{MM}$ risk in the dominant model and allele frequency. Further investigation is needed to gain better insight.

Keywords: Multiple myeloma, Tumor necrosis factor- $\alpha$, Polymorphism, Meta-analysis
III $\ddot{\mathrm{O} z}$

Sonuç: Sonuç olarak, -308G/A polimorfizmi baskın modelde ve allel sıklığında MM riskinde azalma ile ilişkili bulunmuştur. Bu ilişkinin daha iyi anlaşılabilmesi için ileri çalışmalar gereklidir.

Anahtar Sözcükler: Multiple myelom, Tümör nekroz faktör- $\alpha$, Polimorfizm, Meta-analiz

\section{Introduction}

Multiple myeloma (MM) is a bone marrow-based disseminated neoplasm commonly preceded by premalignant monoclonal gammopathy of undetermined significance [1]. Among the hematologic malignancy types, MM accounts for approximately $10 \%$ of diagnosed cases, maintaining the second position after non-Hodgkin's lymphoma [2]. According to the latest statistics, there are 30,330 new MM cases and 12,650 deaths attributed to MM in the United States annually [3]. With the rapid progress made in pharmaceutical research, novel proteasome inhibitors and immune modulatory drugs have been applied in the treatment of MM [4], and the prognosis of MM has significantly improved among all MM patients. Despite the improvement in both treatment and survival, MM is currently regarded as an incurable disease, and the major goal of treatment is to achieve partial or complete remission. Therefore, it is of critical importance to investigate the risk factors of MM and to identify high-risk populations at the early stage of the disease.

Previous studies have revealed that genetic abnormalities contribute to the risk of developing MM, especially genes related to the immune response. For example, the rs2285803 polymorphism located in the human leukocyte antigen (HLA) region was found to be associated with an elevated MM risk in the European population [5] but not in Chinese individuals [6]. Moreover, a study identified several polymorphisms in HLA by applying a novel statistical model, suggesting the important role of HLA in MM [7]. Previous studies have also suggested that mutations in germline lysine-specific demethylase 1 and elongation factor for RNA polymerase II 2 (ELL2) are associated with an elevated risk of MM $[8,9]$. Tumor necrosis factor alpha (TNF- $\alpha$ ) is an important cytokine, and cytotoxin triggers have been implicated in tumor regression, septic shock, and cachexia [10]. Mutations in the promoter region of TNF- $\alpha$ may affect the binding of transcription factors and consequently result in alterations in mRNA expression. The -308G/A polymorphism of TNF- $\alpha$ has been widely investigated in relation to various diseases, including infectious diseases and cancers. The A allele of the $-308 \mathrm{G} / \mathrm{A}$ polymorphism is associated with stronger transcription activity compared with the wild type and increased TNF- $\alpha$ expression in vivo [11]. Moreover, most HLA variations associated with MM can be explained by rs2285803, and we found that the $-308 \mathrm{G} / \mathrm{A}$ polymorphism and rs2285803 are in linkage disequilibrium with a D' value of 0.7308 and an $\mathrm{R}^{2}$ value of 0.0197 . Considering the findings that we observed, in the present study, we conducted a meta-analysis on the -308G/A polymorphism and MM risk in accordance with the Preferred Reporting Items for Systematic Reviews and MetaAnalyses guidance, which would provide information on the association between polymorphisms in both TNF- $\alpha$ and HLA and MM.

\section{Materials and Methods}

\section{Search Strategy and Study Eligibility}

A literature search was independently conducted by two investigators for genetic studies on TNF- $\alpha$ in PubMed, the China National Knowledge Infrastructure (CNKI), Scopus, Web of Science, and Google Scholar databases without any restriction of publication language. All relevant studies reported up to 10 December 2018 and the following key words were searched: "multiple myeloma", "plasma cell", "plasmacell", "plasmacytoma", "myelomatosis", "Kahler's disease", "TNF- $\alpha$ ", "tumor necrosis factor alpha", and "-308G/A".

Studies that fulfilled all the following criteria were included in the meta-analysis: (1) studies used case-control study design; (2) studies evaluated the association between TNF- $\alpha$ polymorphisms and the risk of developing $\mathrm{MM}$; and (3) studies included genotype distribution of TNF- $\alpha$ polymorphisms in both cases and controls and other essential information required to estimate the odds ratio (OR) and 95\% confidence interval (CI). Studies that met any one of the following criteria were excluded: (1) data were not relevant to the association between TNF- $\alpha$ polymorphisms and MM risk; (2) reviews, cases reports, editorial comments, and communications were included; or (3) there were insufficient data to estimate OR and $95 \% \mathrm{Cl}$.

\section{Quality Assessment and Data Extraction}

The Newcastle-0ttawa Scale was used to evaluate the quality of the enrolled studies independently by two investigators. Disagreements between the two investigators were settled by discussions to reevaluate the methodological quality of original studies. 
The extraction of data from individual studies included the following: the surname of the first author, the year of publication, the location of the study, the ethnicity and the source of controls, the genotyping method, the Hardy-Weinberg equilibrium (HWE) in controls, and the count of each TNF- $\alpha$ genotype in $\mathrm{MM}$ cases and controls.

\section{Statistical Analysis}

The strength of the association between TNF- $\alpha$ polymorphism and $\mathrm{MM}$ risk was evaluated by $\mathrm{OR}$ and $95 \% \mathrm{Cl}$. We applied the following models to calculate different ORs: the dominant genetic model (GA+AA vs. GG), the recessive genetic model (AA vs. $G A+G G$ ), and the allele model (A vs. G). Z-tests were used to determine the statistical significance of pooled ORs. The heterogeneity between enrolled studies was assessed by using the 0 -test, and we applied a random-effects model to calculate pooled effect size. Subgroup analysis by ethnicity was performed to estimate and demonstrate the pooled MM risk caused by TNF- $\alpha$ polymorphism in different races. Each study was removed in turn for sensitivity analyses, and the remaining studies were reanalyzed to assess the stability of the results. Moreover, publication bias among enrolled studies was examined using Egger's test, where a p-value of less than 0.10 was considered statistically significant. Metaregression was used to identify the source of heterogeneity among covariates in the presence of heterogeneity. If the intercept was significantly different from zero, the estimate of the effect was considered biased. All statistical analyses were performed with STATA Version 12.0 software (Stata Corp, College Station, TX, USA). All p-values in the present study were two-sided, and $p<0.05$ was considered statistically significant unless otherwise specified.

\section{Results}

\section{Study Identification and Main Characteristics}

In total, we identified 167 records from the PubMed and CNKI databases in a primary literature search, and after removing duplicates, 135 records were subjected to title and abstract screening. Sixteen of them were reviewed in full; two were removed because of the absence of genotype distribution data, and two were excluded due to possible overlapping subjects (Figure 1). Finally, 12 studies met the inclusion criteria for our meta-analysis for evaluating the relationship between the $-308 \mathrm{G} / \mathrm{A}$ polymorphism and MM risk $[12,13,14$, $15,16,17,18,19,20,21,22,23]$. Among these studies, eight were based on Caucasian populations, and the remaining four were conducted with Asian subjects. The quality score average was 7.3, which combined all the enrolled studies together; a score greater than 5 was considered appropriate for inclusion in the meta-analysis. Based on the chi-square test results, the genotype distribution in the control group was consistent with the HWE among all 12 enrolled studies. The name of the first author, year of publication, country, ethnicity, source of controls, genotyping method, and HWE in the control group are listed in Table 1. The quality score of each individual study is shown in Table 2 and the detailed genotype distribution is demonstrated in Table 3.

\section{Quantitative Synthesis}

The genotype distribution of the $-308 \mathrm{G} / \mathrm{A}$ polymorphism in the cases and controls of all enrolled studies was extracted, and based on that, we performed a meta-analysis; the main outcome is demonstrated in Figure 2 and Table 4 . In the dominant model, the $-308 \mathrm{G} / \mathrm{A}$ polymorphism was associated with a reduced $\mathrm{MM}$ risk $(\mathrm{OR}=0.80,95 \% \mathrm{Cl}$ : 0.65-0.97). The

\begin{tabular}{|c|c|c|c|c|c|c|c|}
\hline First author & Year & Country & Ethnicity & $\begin{array}{l}\text { Control } \\
\text { population\# }\end{array}$ & $\begin{array}{l}\text { Genotyping } \\
\text { method }\end{array}$ & $\begin{array}{l}\text { HWE for } \\
\text { controls }\end{array}$ & Quality score \\
\hline Neben et al. [21] & 2002 & Germany & Caucasian & $\mathrm{HB}$ & PCR-RFLP & 0.060 & 7 \\
\hline Yakupova et al. [22] & 2003 & Russia & Caucasian & $\mathrm{HB}$ & PCR-RFLP & 0.665 & 7 \\
\hline Au et al. [23] & 2006 & China & Asian & PB & PCR-RFLP & 0.317 & 8 \\
\hline Brown et al. [17] & 2007 & US & Caucasian & PB & TaqMan & 0.176 & 8 \\
\hline Kádár et al. [13] & 2008 & Hungary & Caucasian & $\mathrm{HB}$ & PCR-RFLP & 0.157 & 7 \\
\hline Du et al. [19] & 2010 & China & Asian & $\mathrm{HB}$ & PCR-RFLP & 0.068 & 8 \\
\hline
\end{tabular}



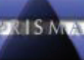

PRISMA 2009 Flow Diagram

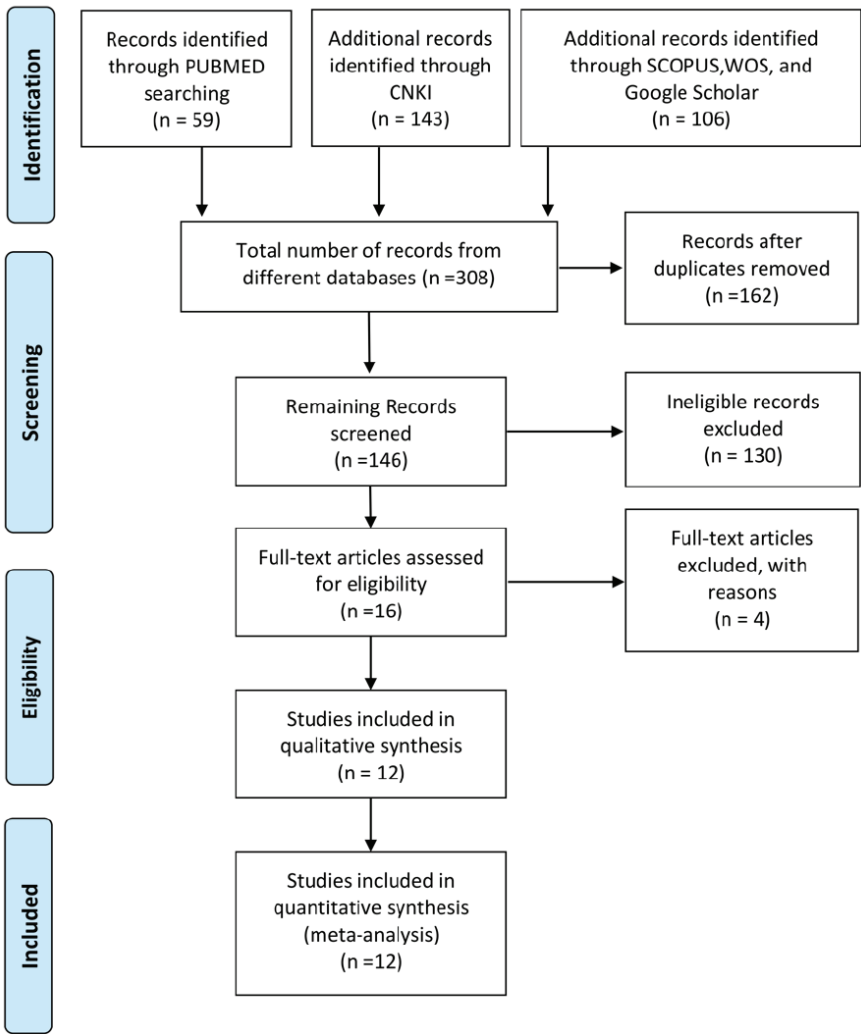

From: Moher D, Liberati A, Tetzlaff J, Altman DG, The PRISMA Group (2009). Preferred Reporting /tems for Systematic Reviews and Meta-
Analyses: The PRISMA Statement. PLoS Med G G6): e1000097. doi: 10.1371/journal. pmed1000097

For more information, visit www.prisma-statement.org.

Figure 1. Preferred Reporting Items for Systematic Reviews and Meta-Analyses (PRISMA) flow diagram for inclusion and exclusion of studies in the meta-analysis.

CNKI: China National Knowledge Infrastructure. subgroup analysis showed a similar association between the $-308 \mathrm{G} / \mathrm{A}$ polymorphism and $\mathrm{MM}$ risk in the Caucasian $(\mathrm{OR}=0.82,95 \% \mathrm{Cl}: 0.68-0.99)$ but not the Asian subgroups $(\mathrm{OR}=0.70,95 \% \mathrm{Cl}: 0.35-1.39)$. Due to the very limited number of AA homozygous carriers, only one Asian study was included in the recessive model, and the overall effect size based on eight studies was 0.84 (95\% Cl: 0.42-1.71). For the allele model, according to our estimation, the A allele of TNF- $\alpha$ $-308 \mathrm{G} / \mathrm{A}$ polymorphism confers a protective effect against MM risk with a pooled OR of 0.83 (95\% Cl: 0.69-0.99) in the overall population, and significance was observed. However, no significant association was observed in the Caucasian $(\mathrm{OR}=0.84,95 \% \mathrm{Cl}: 0.70-1.02)$ and Asian $(\mathrm{OR}=0.75,95 \% \mathrm{Cl}$ : $0.41-1.38$ ) populations in the estimation of subgroup analysis.

\section{Heterogeneity Analysis}

As seen in the quantitative synthesis, heterogeneity was observed in the overall population and in both subgroups in the dominant model; the p-values of the 0-test were all less than 0.05. Similar to the dominant model, intermediate heterogeneity was detected in the allele model. However, no significant heterogeneity was found in the recessive model according to the 0 -test results.

\section{Sensitivity Analysis}

To evaluate the robustness of the present meta-analysis, we performed sensitivity analysis by sequentially removing each eligible study and observing the changes in the overall effect size. As shown in Figure 3, the significance of the overall effect size was not influenced by any single study in both the dominant and allele models, indicating that our results were statistically robust.

\begin{tabular}{|c|c|c|c|c|c|c|c|c|c|c|c|}
\hline \multirow{2}{*}{ First author } & \multirow[t]{2}{*}{ Year } & \multicolumn{4}{|c|}{ Selection } & \multicolumn{2}{|c|}{ Comparability } & \multicolumn{3}{|c|}{ Exposure } & \multirow[t]{2}{*}{ No. of stars } \\
\hline & & S1 & S2 & S3 & S4 & C1 & $\mathrm{C} 2$ & E1 & E2 & E3 & \\
\hline Neben et al. [21] & 2002 & $\star$ & $\star$ & $\star$ & $\star$ & $\star$ & & $\star$ & $\star$ & & 7 \\
\hline Yakupova et al. [22] & 2003 & $\star$ & & $\star$ & $\star$ & $\star$ & $\star$ & $\star$ & $\star$ & & 7 \\
\hline Morgan et al. [12] & 2005 & $\star$ & & $\star$ & $\star$ & $\star$ & $\star$ & $\star$ & $\star$ & & 7 \\
\hline Au et al. [23] & 2006 & $\star$ & $\star$ & $\star$ & $\star$ & $\star$ & $\star$ & $\star$ & $\star$ & & 8 \\
\hline Brown et al. [17] & 2007 & $\star$ & $\star$ & $\star$ & $\star$ & $\star$ & $\star$ & $\star$ & $\star$ & & 8 \\
\hline Kádár et al. [13] & 2008 & $\star$ & & $\star$ & $\star$ & $\star$ & $\star$ & $\star$ & $\star$ & & 7 \\
\hline Nielsen et al. [18] & 2017 & $\star$ & $\star$ & $\star$ & $\star$ & $\star$ & $\star$ & $\star$ & $\star$ & & 8 \\
\hline
\end{tabular}




\section{Publication Bias}

We applied Begg's funnel plot and Egger's test to assess publication bias in the present meta-analysis of the $-308 \mathrm{G} / \mathrm{A}$ polymorphism and MM risk. The funnel plots' shapes of the dominant and allele models (Table 5; Figure 4) did not provide obvious evidence of asymmetry, and all the p-values of Egger's test were greater than 0.05 , providing statistical evidence for the funnel plots' symmetry. Thus, the above results suggest that publication bias was not evident in this meta-analysis.

\section{Meta-regression}

As demonstrated in the previous section, heterogeneity was observed in both the dominant and allele model analyses but
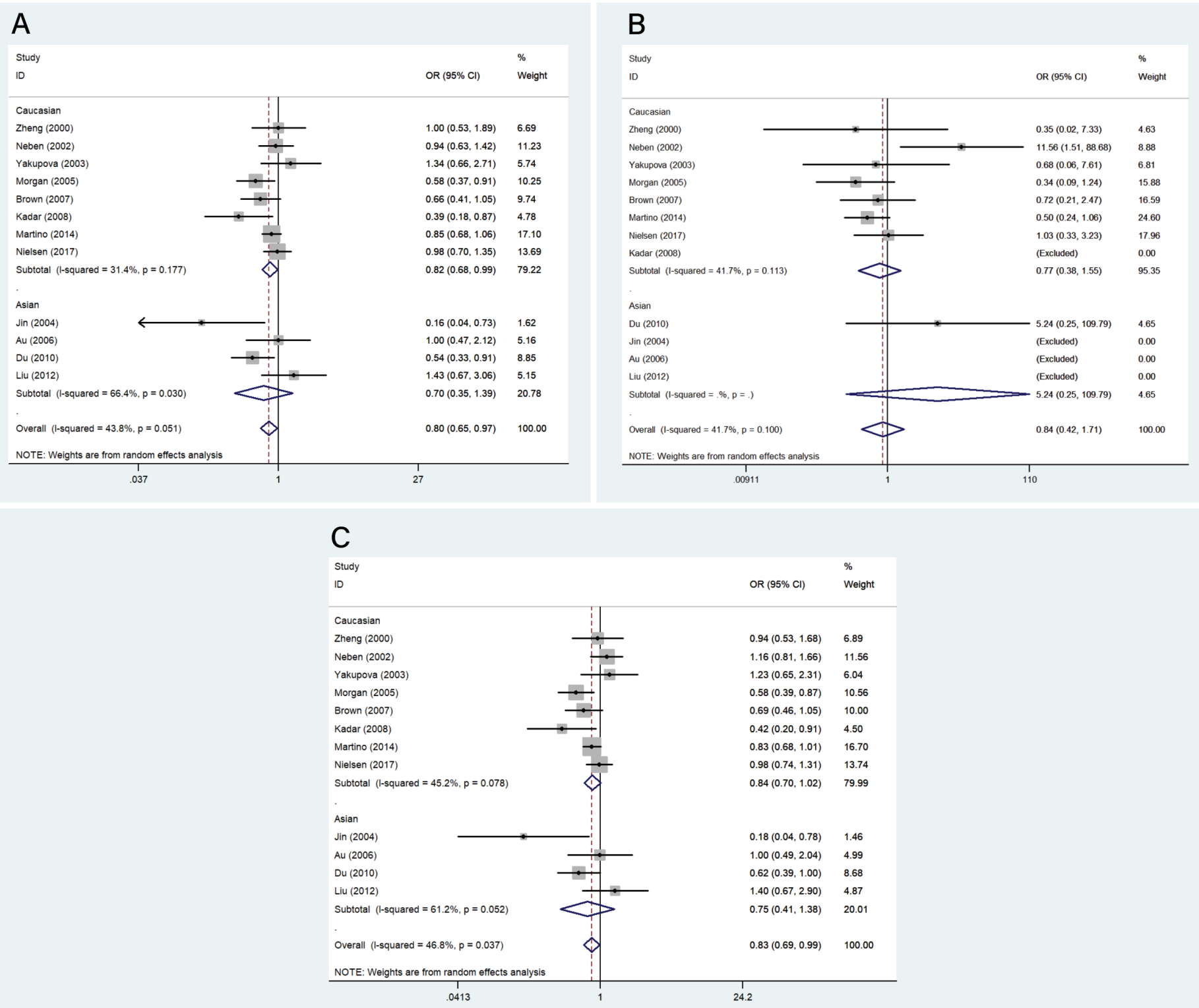

Figure 2 The association of tumor necrosis factor alpha -308G/A polymorphism with multiple myeloma risk in (A) dominant model, (B) recessive model, and (C) allele model.

OR: Odds ratio, $\mathrm{Cl}$ : confidence interval. 
that TNF- $\alpha$ participates in several key processes of tumor progression, including oncogene activation, DNA damage, and tumor metastasis [25]. For instance, it has been reported that TNF- $\alpha$ has elevated expression in colorectal cancer tissue compared with normal colorectal tissue, and that cancer tissues in advanced stages have higher TNF- $\alpha$ expression compared with cancer tissues in earlier stages [26]. As mentioned before, the $-308 \mathrm{G} / \mathrm{A}$ polymorphism is associated with elevated expression of TNF- $\alpha$ mRNA through its effect on transcription. Our metaanalysis comprehensively reviewed published findings and demonstrated that it has a protective effect against MM risk in the dominant model and allele analysis.

Substantial studies have shown that the $-308 \mathrm{G} / \mathrm{A}$ polymorphism is associated with elevated constitutive and inducible protein levels compared with wild-type carriers [27]. A low concentration of TNF- $\alpha$ was observed in subjects carrying the GG genotype, and intermediate and high levels were associated with the GA and AA genotypes, respectively. Therefore, it was reasonable
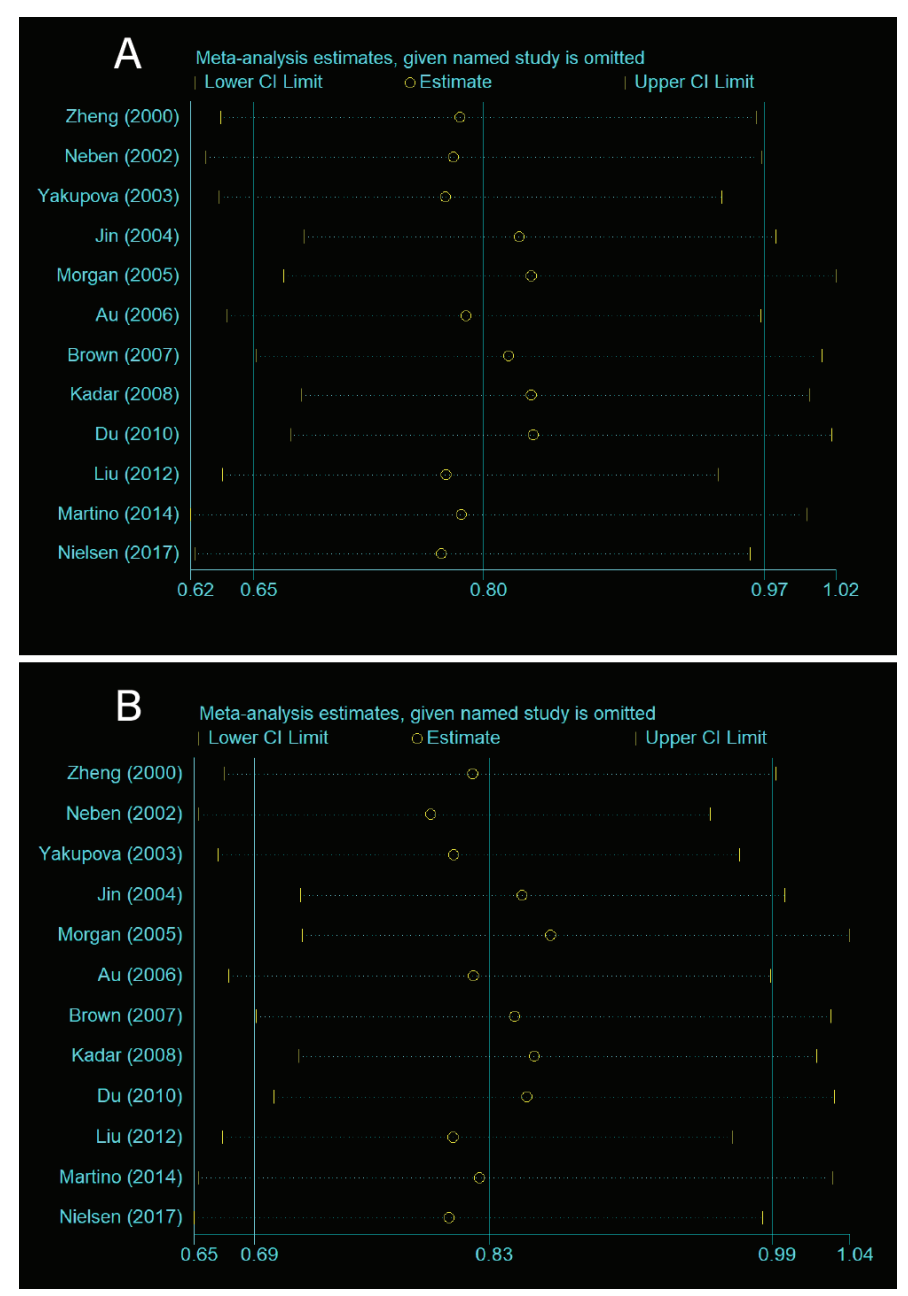

Figure 3. Sensitivity analysis for tumor necrosis factor alpha $-308 \mathrm{G} / \mathrm{A}$ polymorphism in (A) dominant model and (B) allele model.

Cl: Confidence interval. to assume that the $-308 \mathrm{G} / \mathrm{A}$ polymorphism increases the risk of developing MM through its effect on the TNF- $\alpha$ expression level. It has been acknowledged that the inflammation and immune responses triggered by TNF- $\alpha$ lead to the progression of cancer and often predict a worse outcome. A previous study conducted on $44 \mathrm{MM}$ cases demonstrated that MM patients with advanced progression had significantly elevated serum TNF- $\alpha$ levels compared with normal controls [28]. Consistent with this result, Jurisić and Colović [29] examined the TNF- $\alpha$ levels in MM patients and found that serum level positively correlated with clinical stage and osteolysis, which is a severe complication of MM. Moreover, a cell assay revealed that TNF- $\alpha$ was capable of inducing IL-6 expression via the JAK/STAT pathway in U266 MM cells [30]. Thus, both epidemiological observations and laboratory studies support the unfavorable effects of TNF- $\alpha$ on MM. However, our results were inconsistent with the previous findings.

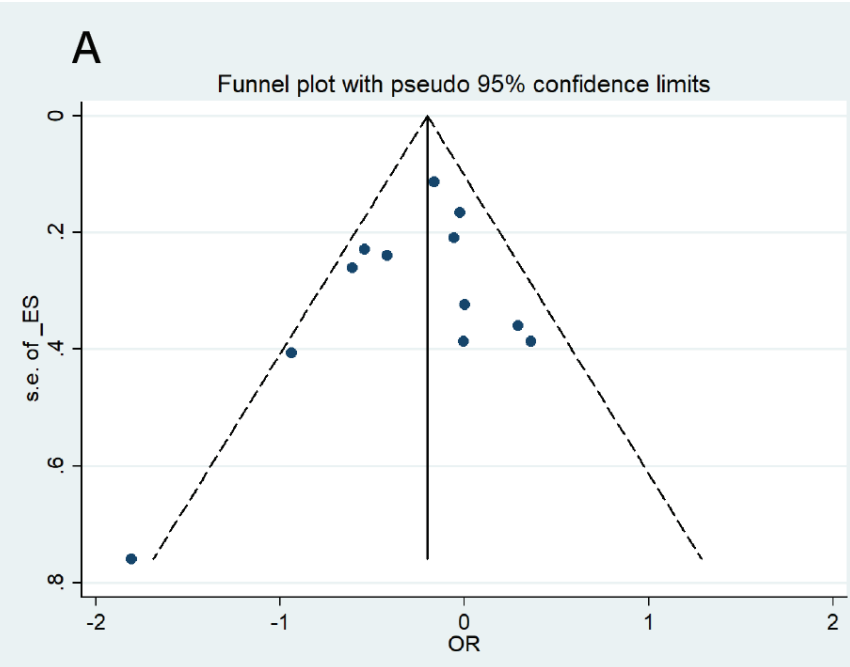

\section{B}

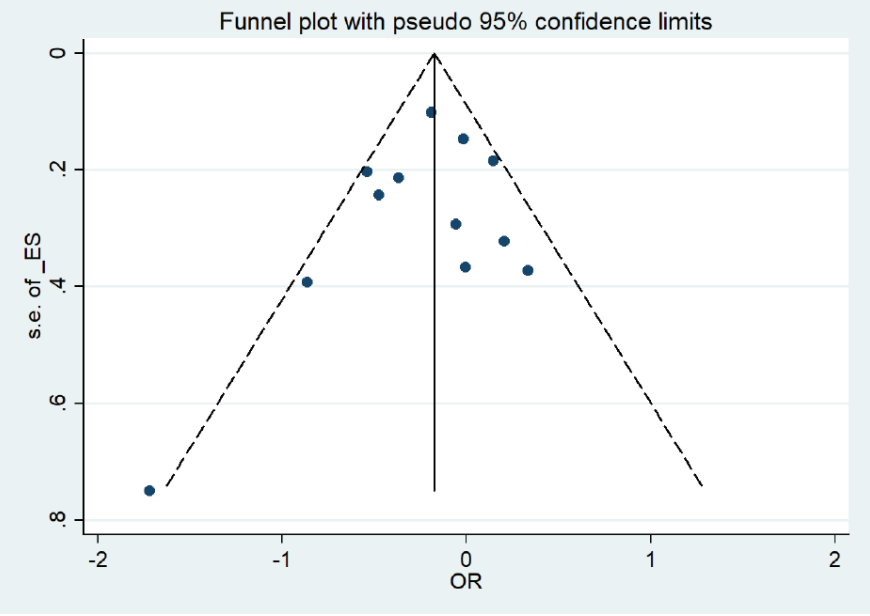

Figure 4. Begg's funnel plot for the evaluation of publication bias of tumor necrosis factor alpha $-\alpha-308 \mathrm{G} / \mathrm{A}$ polymorphism in (A) dominant model and (B) allele model.

OR: Odds ratio. 
The pooled $\mathrm{OR}$ in the dominant and allele model showed a protective effect of the $-308 \mathrm{G} / \mathrm{A}$ polymorphism. A possible explanation is that inflammation caused by elevated TNF- $\alpha$ would definitely promote the progression and development of $M M$, which is confirmed by comparing MM cases in different stages. TNF- $\alpha$ has also been proven to possess anti-tumor effects through various mechanisms. For instance, TNF- $\alpha$ has been shown to have cytotoxic activity in tumor cells in paraformaldehyde-fixed activated monocytes [31]. Moreover, it has been revealed that TNF- $\alpha$ is associated with B-cell proliferation and immunoglobulin production by interacting with TNF-R2 in healthy individuals [32]. Based on these findings, we assume that elevated TNF- $\alpha$ levels can reduce the MM risk by improving immune surveillance and eliminating tumor

\begin{tabular}{|c|c|c|c|c|c|c|c|c|c|}
\hline \multirow{2}{*}{ First author } & \multirow{2}{*}{ Year } & \multicolumn{4}{|c|}{ MM cases } & \multicolumn{4}{|c|}{ Controls } \\
\hline & & GG & GA & AA & Total & GG & GA & AA & Total \\
\hline Zheng et al. [15] & 2000 & 52 & 21 & 0 & 73 & 92 & 35 & 2 & 129 \\
\hline Neben et al. [21] & 2002 & 184 & 57 & 14 & 255 & 142 & 57 & 1 & 200 \\
\hline Yakupova et al. [22] & 2003 & 49 & 19 & 1 & 69 & 72 & 20 & 2 & 94 \\
\hline Jin et al. [14] & 2004 & 54 & 2 & 0 & 56 & 93 & 21 & 0 & 114 \\
\hline Morgan et al. [12] & 2005 & 141 & 36 & 3 & 180 & 158 & 64 & 11 & 233 \\
\hline Au et al. [23] & 2006 & 67 & 15 & 0 & 82 & 80 & 18 & 0 & 98 \\
\hline Brown et al. [17] & 2007 & 99 & 23 & 3 & 125 & 388 & 137 & 18 & 543 \\
\hline Kádár et al. [13] & 2008 & 85 & 9 & 0 & 94 & 111 & 30 & 0 & 141 \\
\hline Du et al. [19] & 2010 & 182 & 26 & 2 & 210 & 170 & 48 & 0 & 218 \\
\hline Liu et al. [20] & 2012 & 73 & 13 & 0 & 86 & 153 & 19 & 0 & 172 \\
\hline Martino et al. [16] & 2014 & 478 & 143 & 9 & 630 & 859 & 289 & 33 & 1181 \\
\hline Nielsen et al. [18] & 2017 & 244 & 94 & 6 & 344 & 250 & 99 & 6 & 355 \\
\hline
\end{tabular}

\begin{tabular}{|c|c|c|c|c|c|c|c|c|}
\hline \multirow[t]{2}{*}{ Genetic model } & \multirow[t]{2}{*}{ Subgroup } & \multirow[t]{2}{*}{ No. of studies } & \multicolumn{3}{|c|}{ Test of association } & \multicolumn{3}{|c|}{ Test of heterogeneity } \\
\hline & & & OR & 95\% Cl & p & Model & $1^{2}$ & p \\
\hline \multirow{3}{*}{ Dominant model } & Overall & 12 & 0.80 & $0.66-0.97$ & $0.024^{*}$ & Random & $43.8 \%$ & $0.046^{*}$ \\
\hline & Caucasian & 8 & 0.82 & $0.68-0.99$ & $0.038^{*}$ & Random & $31.4 \%$ & $0.021^{*}$ \\
\hline & Asian & 4 & 0.70 & 0.36-1.39 & 0.312 & Random & $66.4 \%$ & $0.030^{*}$ \\
\hline \multirow{3}{*}{ Recessive model } & Overall & 8 & 0.84 & $0.42-1.71$ & 0.638 & Random & $41.7 \%$ & 0.100 \\
\hline & Caucasian & 7 & 0.77 & $0.38-1.55$ & 0.460 & Random & $41.7 \%$ & 0.113 \\
\hline & Asian & 1 & 5.24 & $0.25-109.79$ & 0.286 & Random & $\mathrm{N} / \mathrm{A}$ & $N / A$ \\
\hline \multirow{3}{*}{ Allele } & Overall & 12 & 0.83 & 0.69-0.99 & $0.042^{*}$ & Random & $46.8 \%$ & $0.043^{*}$ \\
\hline & Caucasian & 8 & 0.84 & $0.70-1.02$ & 0.072 & Random & $45.2 \%$ & $0.030^{*}$ \\
\hline & Asian & 4 & 0.75 & $0.41-1.38$ & 0.357 & Random & $61.2 \%$ & 0.052 \\
\hline
\end{tabular}

\begin{tabular}{|l|l|l|l|l|l|}
\hline Table 5. The evaluation of publication bias by using Egger's test. \\
\hline Genetic model & Coefficient & Standard error & $\mathbf{t}$ & $\mathbf{p}>\mathbf{~ t ~} \mathbf{I}$ & $\mathbf{9 5 \%} \mathbf{C l}$ \\
\hline Dominant & -0.095 & 0.679 & -0.14 & 0.891 & -1.61 to 1.42 \\
\hline Recessive & 3.982 & 3.075 & 1.30 & 0.243 & -3.54 to 11.51 \\
\hline Allele & -0.081 & 0.709 & -0.11 & 0.912 & -1.66 to 1.50 \\
\hline Cl: Confidence interval.
\end{tabular}




\begin{tabular}{|c|c|c|c|c|c|c|}
\hline Model & Covariate & Coefficient & $\mathrm{Tau}^{2}$ & |2-Res & Adj. $R^{2}$ & $\mathbf{p}$ \\
\hline \multirow{4}{*}{ Dominant } & Year & 0.006 & 0.004 & $47.56 \%$ & $-92.07 \%$ & 0.776 \\
\hline & Ethnicity & 0.116 & 0.025 & $47.38 \%$ & $-28.79 \%$ & 0.690 \\
\hline & Study quality & -0.122 & 0.051 & $48.78 \%$ & $-159.46 \%$ & 0.622 \\
\hline & Genotyping method & -0.237 & 0.039 & $48.80 \%$ & $-102.08 \%$ & 0.902 \\
\hline \multirow{4}{*}{ Allele } & Year & 0.002 & 0.047 & $51.49 \%$ & $-56.55 \%$ & 0.943 \\
\hline & Sample size & 0.001 & 0.051 & $51.53 \%$ & $-69.22 \%$ & 0.982 \\
\hline & Ethnicity & 0.076 & 0.038 & $50.89 \%$ & $-26.30 \%$ & 0.786 \\
\hline & Study quality & -0.145 & 0.050 & $51.03 \%$ & $-66.59 \%$ & 0.513 \\
\hline
\end{tabular}

cells, but in individuals who have already developed MM, the elevated TNF- $\alpha$ level may have unfavorable effects associated with shorter survival time.

In subgroup analysis by ethnicity, we observed contradictory results in the dominant model but not allele frequency. As observed, the $-308 \mathrm{G} / \mathrm{A}$ polymorphism has a protective effect in the Caucasian population but not in the Asian population; we assume that this can be attributed to the limited number of Asian population studies when compared with Caucasian populations. Therefore, it is possible that the subgroup analysis showed a null association in the Asian population. In addition, we also analyzed the difference between genotyping methods employed by included studies. Due to the limited number of included studies, we categorized the genotyping methods as polymerase chain reaction-restriction fragment length polymorphism (PCRRFLP), which is a classic genotyping method, and others, as one subgroup. PCR-RFLP is a technique that detects DNA sequence mutations by the lengths of fragments after digestion with specific restriction endonucleases [33]. However, it requires a larger amount of DNA and often involves multiple manual processes. In addition, techniques such as TaqMan offer rapid processing and a more sensitive way to determine SNPs with distinct fluorescent dye-based technology [34]. The subgroup analysis showed a similar trend between subgroups in both the dominant model and allele analysis. Based on the results, we assume that the genotyping methods did not interfere with the overall effect size.

\section{Study Limitations}

Some limitations of our study must be mentioned. First, the rare frequency of the AA genotype in some of the included studies led to the unavailability of these studies in the recessive model. Second, the present study failed to identify the source of heterogeneity using meta-regression, although heterogeneity was rather intermediate.
Nonetheless, we provided novel insight into the association investigated in this study, suggesting that elevated TNF- $\alpha$ levels may reduce MM risk, which deserves investigation of its underlying mechanism.

\section{Conclusion}

In summary, only intermediate heterogeneity was detected in two genetic models with no sign of publication bias. We attempted to identify the source of heterogeneity by conducting meta-regression; however, no contribution to the heterogeneity was found. The sensitivity analysis indicated that the pooled effect size was not influenced by any single study, indicating satisfactory robustness of the present study. Therefore, we concluded that the synthesized effects and conclusions about TNF- $\alpha$ polymorphism were solid.

\section{Ethics}

Ethics Committee Approval: No applicable, since this is a metaanalysis.

Informed Consent: Meta-analysis study.

\section{Authorship Contributions}

Concept: Y. Lin; Design: Y. Lin; Data Collection or Processing: Y. Li; Analysis or Interpretation: Y. Li, Y. Lin; Literature Search: Y. Li, Y. Lin; Writing: Y. Li, Y. Lin.

Conflict of Interest: The authors of this paper have no conflicts of interest, including specific financial interests, relationships, and/or affiliations relevant to the subject matter or materials included.

\section{References}

1. Kyle RA, Therneau TM, Rajkumar SV, Offord JR, Larson DR, Plevak MF, Melton $\sqcup 3 \mathrm{rd}$. A long-term study of prognosis in monoclonal gammopathy of undetermined significance. N Engl J Med 2002;346:564-569. 
2. Morabito F, Recchia AG, Mazzone C, Gentile M. Targeted therapy of multiple myeloma: the changing paradigm at the beginning of the new millennium. Curr Cancer Drug Targets 2012;12:743-756.

3. Siegel RL, Miller KD, Jemal A. Cancer statistics, 2016. CA Cancer J Clin 2016;66:7-30

4. Palumbo A, Anderson K. Multiple myeloma. N Engl J Med 2011;364:1046-1060.

5. Chubb D, Weinhold $N$, Broderick $P$, Chen $B$, Johnson DC, Försti $A$, Vijayakrishnan J, Migliorini G, Dobbins SE, Holroyd A, Hose D, Walker BA, Davies FE, Gregory WA, Jackson GH, Irving JA, Pratt G, Fegan C, Fenton $J A$, Neben $K$, Hoffmann P, Nöthen MM, Mühleisen TW, Eisele L, Ross FM, Straka C, Einsele $H$, Langer C, Dörner E, Allan JM, Jauch A, Morgan GJ, Hemminki K, Houlston RS, Goldschmidt H. Common variation at $3 q 26.2$, $6 \mathrm{p} 21.33,17 \mathrm{p} 11.2$ and $22 q 13.1$ influences multiple myeloma risk. Nat Genet 2013;45:1221-1225.

6. Wang X, An G, Wang J, Zhang Y, Li Q, Wei H, Qiu L, Ru K. The association of HLA-C alleles with multiple myeloma in Chinese patients. Exp Hematol Oncol 2018;7:19.

7. Beksac M, Gragert L, Fingerson S, Maiers M, Zhang MJ, Albrecht M, Zhong X, Cozen W, Dispenzieri A, Lonial S, Hari P. HLA polymorphism and risk of multiple myeloma. Leukemia 2016;30:2260-2264.

8. Wei X, Calvo-Vidal MN, Chen S, Wu G, Revuelta MV, Sun J, Zhang J, Walsh MF, Nichols KE, Joseph V, Snyder C, Vachon CM, McKay JD, Wang SP, Jayabalan DS, Jacobs LM, Becirovic D, Waller RG, Artomov M, Viale A, Patel J, Phillip J, Chen-Kiang S, Curtin K, Salama M, Atanackovic D, Niesvizky R, Landgren O, Slager SL, Godley LA, Churpek J, Garber JE, Anderson KC, Daly MJ, Roeder RG, Dumontet C, Lynch HT, Mullighan CG, Camp NJ, Offit K, Klein RJ, Yu H, Cerchietti L, Lipkin SM. Germline lysine-specific demethylase 1 (LSD1/KDM1A) mutations confer susceptibility to multiple myeloma. Cancer Res 2018;78:2747-2759.

9. Li N, Johnson DC, Weinhold N, Kimber S, Dobbins SE, Mitchell JS, Kinnersley B, Sud A, Law PJ, Orlando G, Scales M, Wardell CP, Försti A, Hoang PH, Went $M$, Holroyd A, Hariri F, Pastinen T, Meissner T, Goldschmidt H, Hemminki K, Morgan GJ, Kaiser M, Houlston RS. Genetic predisposition to multiple myeloma at $5 q 15$ is mediated by an ELL2 enhancer polymorphism. Cell Rep 2017;20:2556-2564.

10. Kriegler M, Perez C, DeFay K, Albert I, Lu SD. A novel form of TNF/cachectin is a cell surface cytotoxic transmembrane protein: ramifications for the complex physiology of TNF. Cell 1988;53:45-53.

11. Wilson AG, Symons JA, McDowell TL, McDevitt HO, Duff GW. Effects of a polymorphism in the human tumor necrosis factor alpha promoter on transcriptional activation. Proc Natl Acad Sci U S A 1997;94:3195-3199.

12. Morgan GJ, Adamson PJ, Mensah FK, Spink CF, Law GR, Keen $\sqcup$, Roman E, Davies FE, Rollinson S, Child JA, Bidwell JL. Haplotypes in the tumour necrosis factor region and myeloma. Br J Haematol 2005;129:358-365.

13. Kádár K, Kovács M, Karádi I, Melegh B, Pocsai Z, Mikala G, Tordai A, Szilágyi A, Adány R, Füst G, Várkonyi J. Polymorphisms of TNF-alpha and LT-alpha genes in multiple myeloma. Leuk Res 2008;32:1499-1504.

14. Jin $H Y$, Wang DX, Guo C, Chen $X D$, Jiang $H$, Hou J. Relationship between the polymorphism of promoter region in TNF- $\alpha$ gene and the susceptibility to multiple myeloma. Current Immunology 2004;24:407-409.

15. Zheng $C$, Huang DR, Bergenbrant $S$, Sundblad $A$, Osterborg $A$, Björkholm $M$, Holm G, Yi Q. Interleukin 6, tumour necrosis factor $\alpha$, interleukin $1 \beta$ and interleukin 1 receptor antagonist promoter or coding gene polymorphisms in multiple myeloma. Br J Haematol 2000;109:39-45.

16. Martino A, Campa D, Jurczyszyn A, Martínez-López J, Moreno MJ, Varkonyi J, Dumontet C, Garcia-Sanz R, Gemignani F, Jamroziak K, Stępieł A, Jacobsen SE, Andersen V, Jurado M, Landi S, Rossi AM, Lesueur F, Marques H, Dudziński M, Wątek M, Moreno V, Orciuolo E, Petrini M, Reis RM, Ríos R, Sainz J, Vogel U, Buda G, Vangsted AJ, Canzian F. Genetic variants and multiple myeloma risk: IMMEnSE validation of the best reported associations--an extensive replication of the associations from the candidate gene era. Cancer Epidemiol Biomarkers Prev 2014;23:670-674.
17. Brown EE, Lan $\mathrm{Q}$, Zheng T, Zhang Y, Wang SS, Hoar-Zahm S, Chanock SJ, Rothman N, Baris D. Common variants in genes that mediate immunity and risk of multiple myeloma. Int J Cancer 2007;120:2715-2722.

18. Nielsen KR, Rodrigo-Domingo $M$, Steffensen $R$, Baech J, Bergkvist KS, Oosterhof L, Schmitz A, Bødker JS, Johansen P, Vogel U, Vangsted A, Dybkær K, Bøgsted M, Johnsen HE. Interactions between SNPs affecting inflammatory response genes are associated with multiple myeloma disease risk and survival. Leuk Lymphoma 2017;58:2695-2704.

19. Du J, Yuan Z, Zhang C, Fu W, Jiang H, Chen B, Hou J. Role of the TNF- $\alpha$ promoter polymorphisms for development of multiple myeloma and clinical outcome in thalidomide plus dexamethasone. Leuk Res 2010;34:1453-1458.

20. Liu Y, Zhang P, Song W, Bai X, Liu J, Song B. Polymorphisms of tumor necrosis factor and susceptibility to multiply myeloma. Chin J Cancer Prev Treat 2012;19:1696-1699.

21. Neben $K$, Mytilineos J, Moehler TM, Preiss A, Kraemer A, Ho AD, Opelz G, Goldschmidt $\mathrm{H}$. Polymorphisms of the tumor necrosis factor-alpha gene promoter predict for outcome after thalidomide therapy in relapsed and refractory multiple myeloma. Blood 2002;100:2263-2265.

22. Yakupova EV, Grinchuk OV, Kalimullina DKh, Bakirov BA, Galimova RR, Makarova OV, Khusnutdinova EK, Viktorova TV. Molecular genetic analysis of the interleukin 6 and tumor necrosis factor alpha gene polymorphisms in multiple myeloma. Mol Biol (Mosk) 2003;37:420-424.

23. Au WY, Fung A, Wong KF, Chan $\mathrm{CH}$, Liang R. Tumor necrosis factor alpha promoter polymorphism and the risk of chronic lymphocytic leukemia and myeloma in the Chinese population. Leuk Lymphoma 2006;47:2189-2193.

24. Despotovic M, Stoimenov TJ, Stankovic I, Pavlovic D, Sokolovic D, Cretkovic T, Kocic G, Basic J, Veljkovic A, Djordjevic B. Gene polymorphisms of tumor necrosis factor alpha and antioxidant enzymes in bronchial asthma. Adv Clin Exp Med 2015;24:251-256.

25. Balkwill F. Tumour necrosis factor and cancer. Nat Rev Cancer 2009;9:361-371.

26. Al Obeed OA, Alkhayal KA, Al Sheikh A, Zubaidi AM, Vaali-Mohammed MA, Boushey R, Mckerrow JH, Abdulla MH. Increased expression of tumor necrosis factor- $\alpha$ is associated with advanced colorectal cancer stages. World J Gastroenterol 2014;20:18390-18396.

27. Abraham $\sqcup$, Kroeger KM. Impact of the -308 TNF promoter polymorphism on the transcriptional regulation of the TNF gene: relevance to disease. J Leukoc Biol 1999;66:562-566.

28. Filella X, Blade J, Guillermo AL, Molina R, Rozman C, Ballesta AM. Cytokines (IL-6, TNF-alpha, IL-1alpha) and soluble interleukin-2 receptor as serum tumor markers in multiple myeloma. Cancer Detect Prev 1996;20:52-56.

29. Jurisić V, Colović M. Correlation of sera TNF-alpha with percentage of bone marrow plasma cells, LDH, $\beta 2$-microglobulin, and clinical stage in multiple myeloma. Med Oncol 2002;19:133-139.

30. Lee C, Oh JI, Park J, Choi JH, Bae EK, Lee HJ, Jung WJ, Lee DS, Ahn KS, Yoon SS. TNF $\alpha$ mediated IL-6 secretion is regulated by JAK/STAT pathway but not by MEK phosphorylation and AKT phosphorylation in U266 multiple myeloma cells. Biomed Res Int 2013;2013:580135.

31. Fishman M. Cytolytic activities of activated macrophages versus paraformaldehyde-fixed macrophages; soluble versus membraneassociated TNF. Cell Immunol 1991;137:164-174.

32. Aversa G, Punnonen J, de Vries JE. The 26-kD transmembrane form of tumor necrosis factor alpha on activated CD4+ $T$ cell clones provides a costimulatory signal for human B cell activation. J Exp Med 1993;177:1575-1585.

33. Ghamari E, Farnia P, Saif S, Marashian M, Ghanavi J, Farnia P, Velayati AA. Comparison of single nucleotide polymorphisms [SNP] at TNF- $\alpha$ promoter region with TNF receptor 2 (TNFR2) in susceptibility to pulmonary tuberculosis; using PCR-RFLP technique. Am J Clin Exp Immunol 2016;5:55-61.

34. Shen GQ, Abdullah KG, Wang OK. The TaqMan method for SNP genotyping. Methods Mol Biol 2009;578:293-306. 